\title{
NEW SPECIES OF HARASUPIA WITH A REVISED KEY TO THE SPECIES (HOMOPTERA: CICADELLIDAE: COELIDIINAE)
}

\author{
M. W. Nielson
}

Aвstract.-Five new species of Harasupia in the tribe Teruliini are described and illustrated. These include austini, baja, mexicana, retrorsa, and ungula, all from Mexico. A revised key to 12 known species is also given.

Harasupia Nielson is one of two genera in the tribe Teruliini that is Neogeic in distribution. The origin of the group, however, is believed to be Neotropical. All other genera in the tribe occupy the Neotropical realm except for one Ethiopian species of Biadorus Nielson. While most of the species of Harasupia occur in Mexico, its range extends as far south as Costa Rica (bifurcata Nielson) and north to Arizona (snowi [Lawson]). The latter species is common and has been collected on Arctostaphylos sp. in Arizona by the author. Host records of the remaining species are nonexistent or hosts are poorly known.

Descriptions of five new species in this paper add to seven previously known species and thus enhance the taxonomic affinities of the group (Nielson 1979, 1983). The genus is singularly characterized by a unique aedeagus with two appendagelike, asymmetrical structures of bizarre configurations in the distal $2 / 3$ to $1 / 3$ of the shaft. The gonoduct and gonopore are cryptic, or difficult to discern, which is unusual among leafhoppers.

\section{Key to Males of Harasupia}

1. Pygofer with small caudodorsal or caudoventral lobe .

- Pygofer with long, prominent mesal spine on caudodorsal margin, spine directed ventrad (Fig. 1) . . . ........... mexicana, n. sp.

2(1). Aedeagus with 2 long, appendagelike processes originating subbasally (Nielson 1979, Fig. 111) . . 3

- Aedeagus with 2 long or 2 short appendagelike processes originating medially or in distal $2 / 3$ of shaft, respectively (Nielson 1979, Figs. 117, 143) .......................

3(2). Aedeagus with 3 stout setae subdistally on ventral appendagelike process (Nielson 1983, Figs. $5,6) \ldots \ldots \ldots \ldots \ldots \ldots$ trispinata Nielson
- Aedeagus with tuft of dense setae distally on ventral appendagelike process (Nielson 1979, Figs. 110, 111) marginata $($ Stål

4(2). Style with short distal apophysis, length about as long as broadest basal part in lateral view (Nielson 1979, Figs. 122, 145

- Style with very long distal apophysis, length much longer than broadest basal part in ventral view (Figs. 17, 22, 29)

5(4). Aedeagus with appendagelike processes separated near middle of shaft, appendages with spines or setae

- Aedeagus with appendagelike processes separated near distal 1/3 of shaft, appendages glabrous (Nielson 1979, Figs. 142, 143)

stipulata Nielson

6(5). Aedeagus with ventral appendage with 4 long, fingerlike distal spines (Nielson 1979, Fig. 117) sinistra Nielson

- Aedeagus with ventral appendage with numerous distal setae (Nielson 1979, Fig. 126).

\section{bifurcata Nielson}

7(4). Aedeagus with one or both appendagelike processes clawed, or with clawlike secondary structures (Fig. 14, Nielson 1979, Fig. 136)

- Aedeagus with appendagelike processes not clawed, ventral appendage with numerous spines (Nielson 1979, Fig. 132)

pustulata (Spångberg)

2 8(7). Plate long and narrow (Figs. 18, 24); style

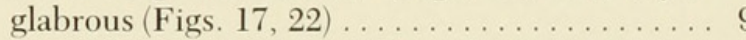

- Plate long and very broad (Fig. 12); style with distal setae (Figs. 10, 11) . . . . . retrorsa, n. sp.

9(8). Aedeagus with basal appendage clawed or with clawlike configuration in lateral view (Figs. 20, 27) . . . . . . . . . . . . . . . . . . . 10

- Aedeagus with basal appendage not clawed in lateral view, but consisting of long process with cryptic gonoduct (Fig. 14) ........ austini, n. sp.

10(9). Aedeagus with basal and distal appendages clawed or clawlike configuration in lateral view (Fig. 21)

${ }^{1}$ Monte L. Bean Life Science Museum, Brigham Young University, Provo, Utah 84602 

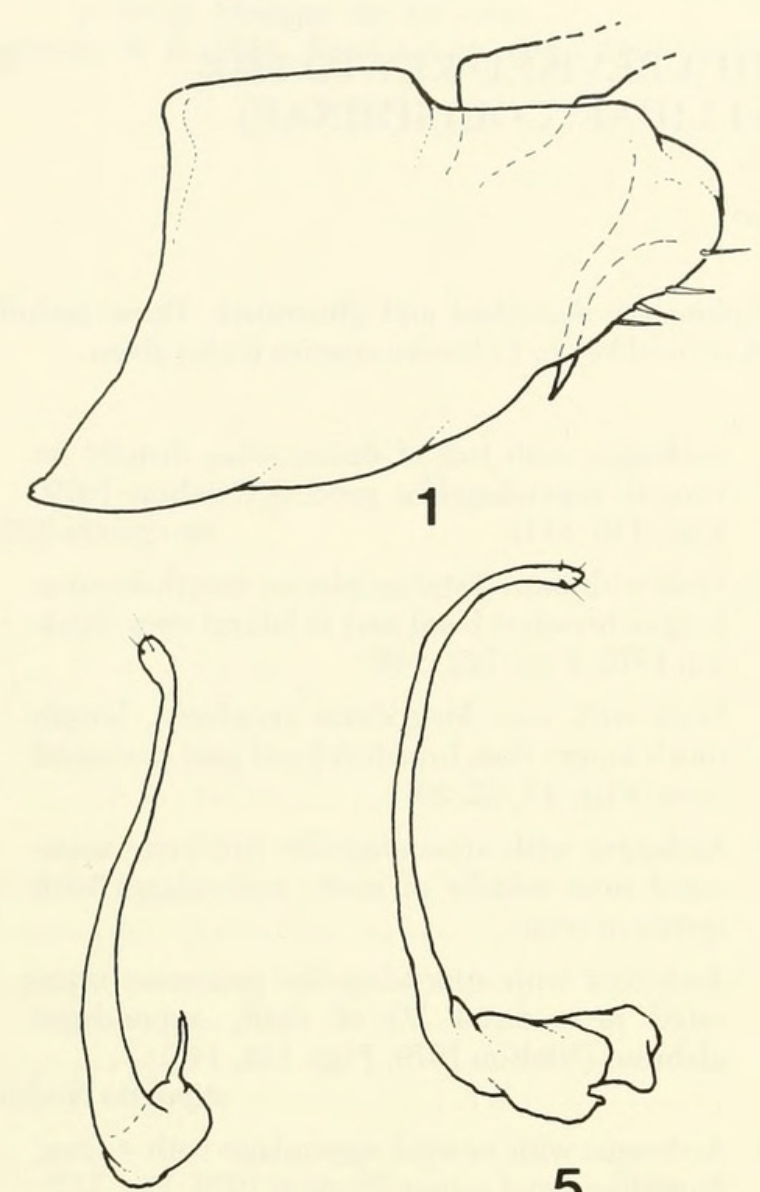

4

5

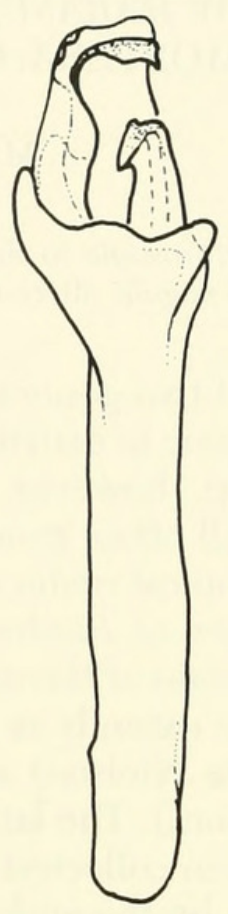

3

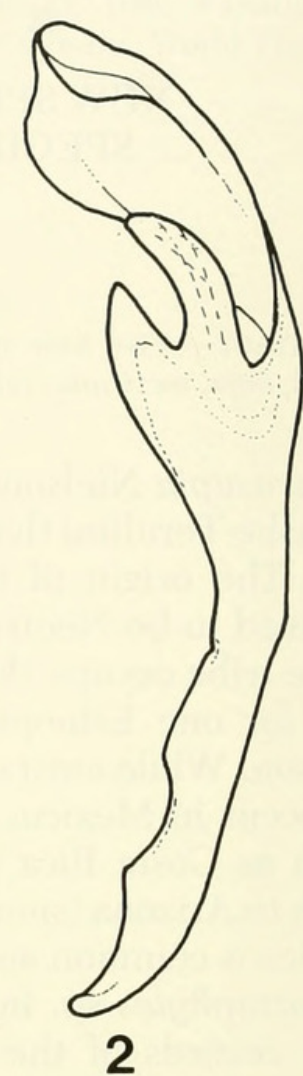

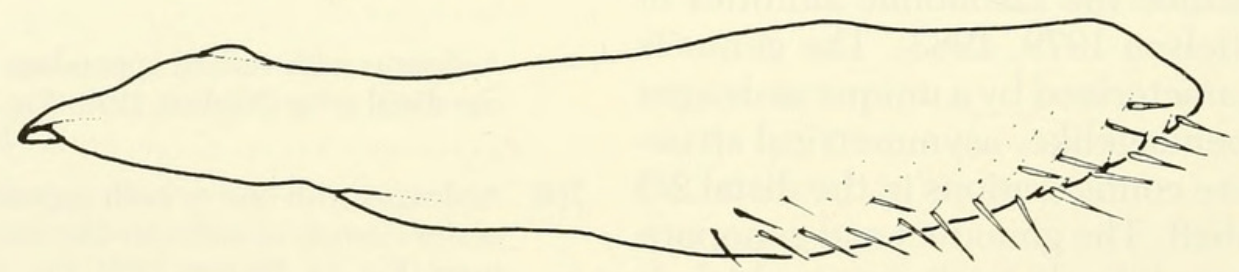

6

Figs. 1-6. Harasupia mexicana, n. sp.: 1, male pygofer, lateral view; 2, aedeagus, lateral view; 3, aedeagus, dorsal view; 4 , style, ventral view; 5 , style, lateral view; 6 , plate, ventral view.

- Aedeagus with only basal appendage clawed, distal appendage long and narrow in lateral view (Fig. 20) ungula, n. sp

11(10). Aedeagus with rami of basal and distal appendages long and narrow in lateral view (Nielson 1979, Fig. 136) snowi (Lawson)

- Aedeagus with basal rami of basal appendage bilobed, distal rami narrow, attenuated, and curved dorsally; rami of distal appendage broad and shallowly bilobed distally in lateral view (Fig. 27) baja, n. sp

\section{Harasupia mexicana, $\mathrm{n}$. sp.}

Figs. 1-6

LENGTH. - Male $7.20 \mathrm{~mm}$.

General color dark brown with costa and claval cells translucent, some anteapical and apical cells partly translucent; crown creamy; eyes rufous; clypeus light creamy with rufous longitudinal band along lateral margins. Similar in general habitus to ungula, $\mathrm{n}$. sp. but larger and with distinctive male genitalia.

Head narrower than pronotum; crown produced anteriorly, disc narrow, narrower than eyes; eyes large, elongate-ovoid; pronotum short, median length less than median length of crown; scutellum short, about equal in length to crown; forewing and venation typical (right forewing missing on type specimen); clypeus long and narrow, with faint but complete median longitudinal carina; 


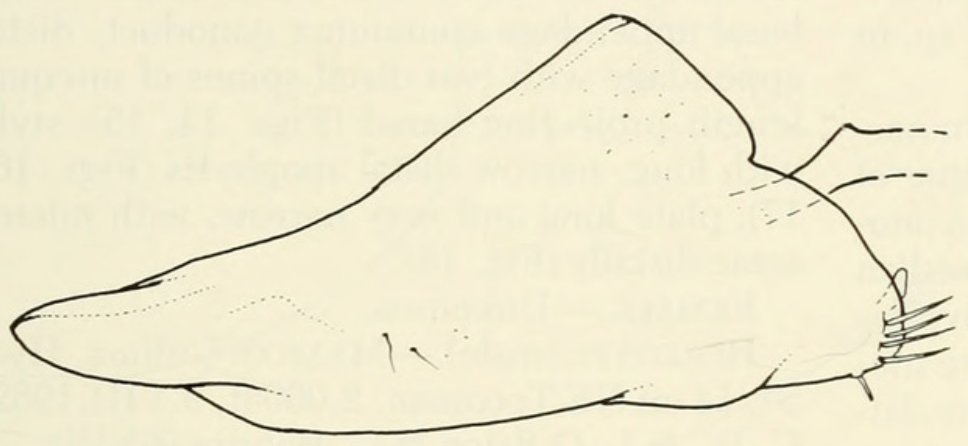

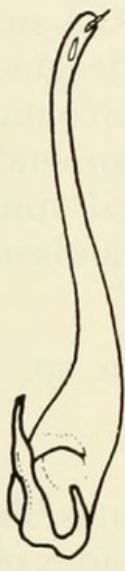

10
7

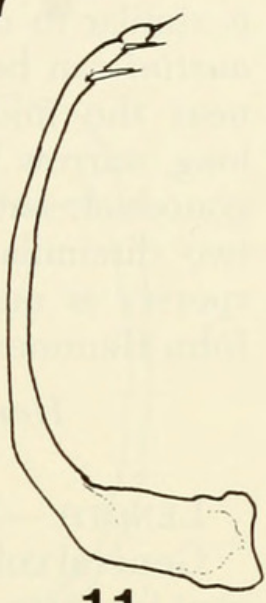

11
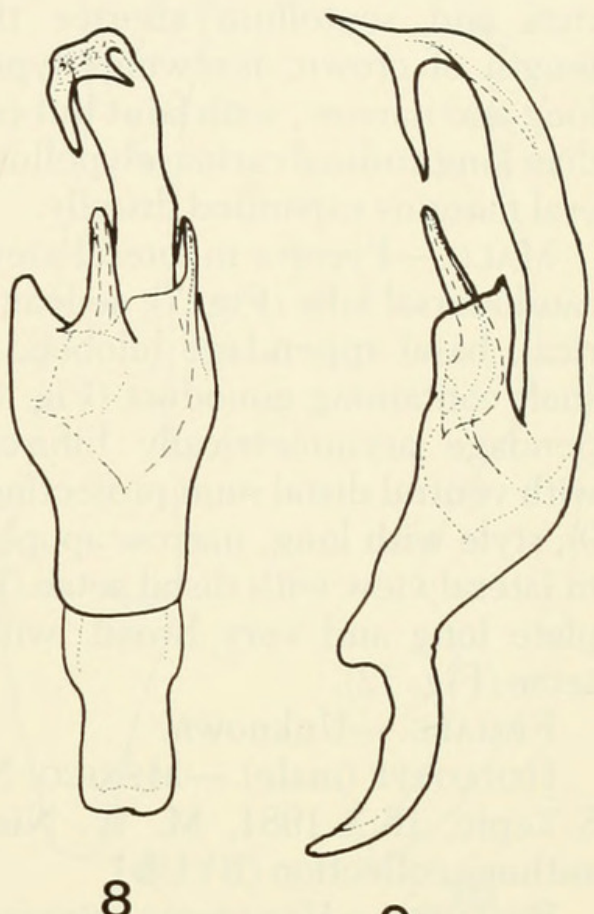

9

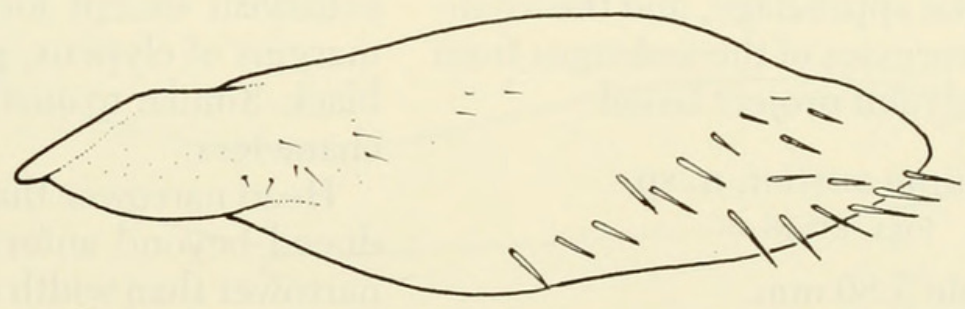

12

Figs. 7-12. Harasupia retrorsa, n. sp.: 7, male pygofer, lateral view; 8 , aedeagus, dorsal view; 9 , aedeagus, lateral view; 10 , style, dorsal view; 11 , style, lateral view; 12 , plate, ventral view.

clypellus long, narrow, lateral margins expanded distally.

MALE.-Pygofer in lateral view with long, narrow spine originating mesally on caudodorsal margin, spine directed ventrally (Fig. 1); aedeagus asymmetrical, basal appendage bilobed in dorsal view (Fig. 3) with lateral process containing gonoduct (Fig. 2), distal appendage broad in lateral view (Fig. 2); style with long, narrow apophysis, curved in lateral view and with distal setae (Figs. 4, 5); plate long and narrow, setaceous on ventral margin in distal half (Fig. 6).

Female.-Unknown.
Holotype (male).-Mexico: $24 \mathrm{mi} \mathrm{W} \mathrm{La}$ Ciudad, 20. VII. 1964, L. Kelton (CNC).

REMARKS.-This species can be distinguished from all known members of Harasupia by the unique spine arising mesally on the caudodorsal margin of the pygofer.

\section{Harasupia retrorsa, n. sp.}

Figs. 7-12

LENGTH. - Male $5.50 \mathrm{~mm}$.

General color dark brown, veins of forewings deep brown, nearly all cells translucent; crown, pronotum, scutellum, and face light yellow; clypeus with rufous, broad, 
longitudinal band on lateral margins (specimen slightly teneral). Similar to baja, n. sp. in aedeagal characters.

Head narrower than pronotum; crown narrow, produced beyond anterior margin of eyes, disc narrower than width of eyes; pronotum and scutellum shorter than median length of crown; forewings typical; clypeus long and narrow, with faint but complete median longitudinal carina; clypellus narrow, lateral margins expanded distally.

MALE.-Pygofer in lateral view with small caudodorsal lobe (Fig. 7); aedeagus asymmetrical, basal appendage bilobed, with medial shaft containing gonoduct (Fig. 8), distal appendage asymmetrically bifurcate distally, with ventral distal rami projecting basad (Fig. 9); style with long, narrow apophysis, curved in lateral view with distal setae (Figs. 10, 11); plate long and very broad, with numerous setae (Fig. 12).

Female.-Unknown.

Holotype (male).-Mexico: Nayarit, $8 \mathrm{mi}$ S Tepic, 18.X.1981, M. W. Nielson, in the author's collection (BYU).

REMARKS.-Harasupia retrorsa can be separated from baja, n. sp. by the broader plate, the narrower distal appendage, and the asymmetrical distal processes of the aedeagus from which the ventral rami project basad.

\section{Harasupia austini, n. sp.}

Figs. 13-18

LENGTH.-Male $5.80 \mathrm{~mm}$.

General color blackish; forewings with costa and apex of clavus translucent; crown and face yellowish; pronotum and base of scutellum black; clypeus with pale, rufous, longitudinal band on lateral margins. Similar to retrorsa, $\mathrm{n}$. sp. in aedeagal characters.

Head narrower than pronotum; crown produced beyond anterior margin of eyes, disc about as wide as width of eyes; eyes large, nearly globular; pronotum shorter than median length of crown and scutellum; scutellum with median length greater than median length of crown; forewings and venation typical; clypeus long and narrow, with faint but complete median longitudinal carina; clypellus narrow with lateral margins expanded distally.

MALE.-Pygofer in lateral view with small caudodorsal lobe (Fig. 13); aedeagus asymmetrical, with small spine near middle on dor- sal margin in lateral view, and single, long, basal appendage containing gonoduct, distal appendage with two distal spines of unequal length projecting basad (Figs. 14, 15); style with long, narrow distal apophysis (Figs. 16, $17)$; plate long and very narrow, with microsetae distally (Fig. 18).

Female.-Unknown.

Holotype (male)._-Mexico: Colima, Hwy 54, $14 \mathrm{mi} \mathrm{NE}$ Tecoman, 2,000 ft, 9.VIII.1982, C. W. \& L. O’Brien \& G. Wibner (BYU).

REMARKS.-From baja, n. sp., to which it is similar in certain male genital characters, austini can be separated by the small spine near the middle of the aedeagus, by the long, narrow basal appendage containing the gonoduct, and by the distal appendage with two dissimilarly shaped distal spines. This species is named for my grandson, Austin John Hammer.

\section{Harasupia ungula, n. sp.}

Figs. 19-24

\section{LENGTH.-Male $7.20 \mathrm{~mm}$.}

General color black; forewings blackish except for costa, cells of clavus, apex of anteapical cells, and base of apical cells, yellowish translucent, veins well marked; head and face yellowish except for lateral rufous band on margins of clypeus; pronotum and scutellum black. Similar to austini, n. sp. in male genital characters.

Head narrower than pronotum; crown produced beyond anterior margin of eyes, disc narrower than width of eyes; eyes large, semiglobular; pronotum short, median length less than median length of crown; scutellum with median length greater than median length of crown; forewings and venation typical; clypeus with weak but complete median longitudinal carina; clypellus narrow, lateral margins expanded distally.

MALE.-Pygofer in lateral view with small caudodorsal lobe (Fig. 19); aedeagus asymmetrical, basal appendage with dorsal rami enlarged, ventral rami narrow and containing gonoduct in lateral view (Fig. 20), distal appendage long and narrow in lateral view, compressed in dorsal view (Fig. 21); style with long, narrow distal apophysis, curved in lateral view (Figs. 22, 23); plate long, broad along middle third, setaceous (Fig. 24).

Female. - Unknown.

Holotype (male).-Mexico: $3 \mathrm{mi} \mathrm{S}$ El Salto, 21.VI.1964, L. Kelton (CNC). 


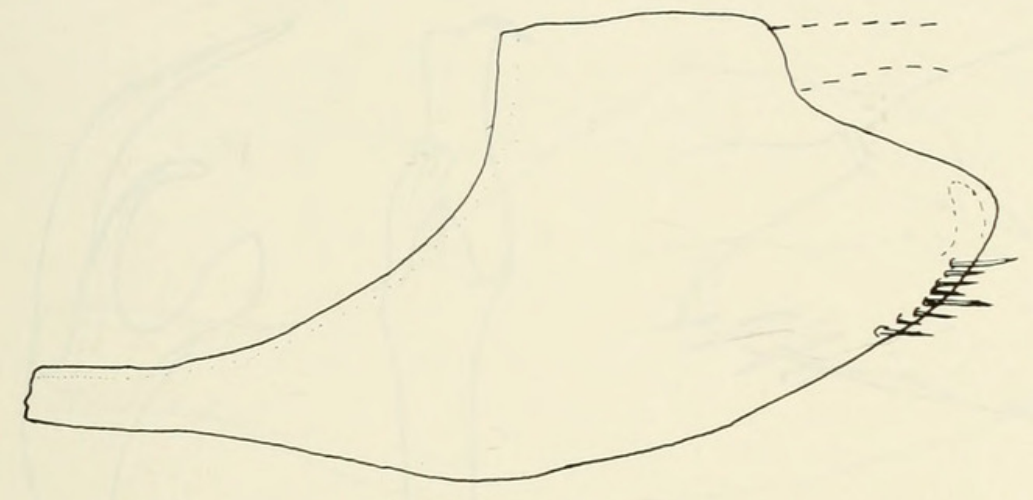

13
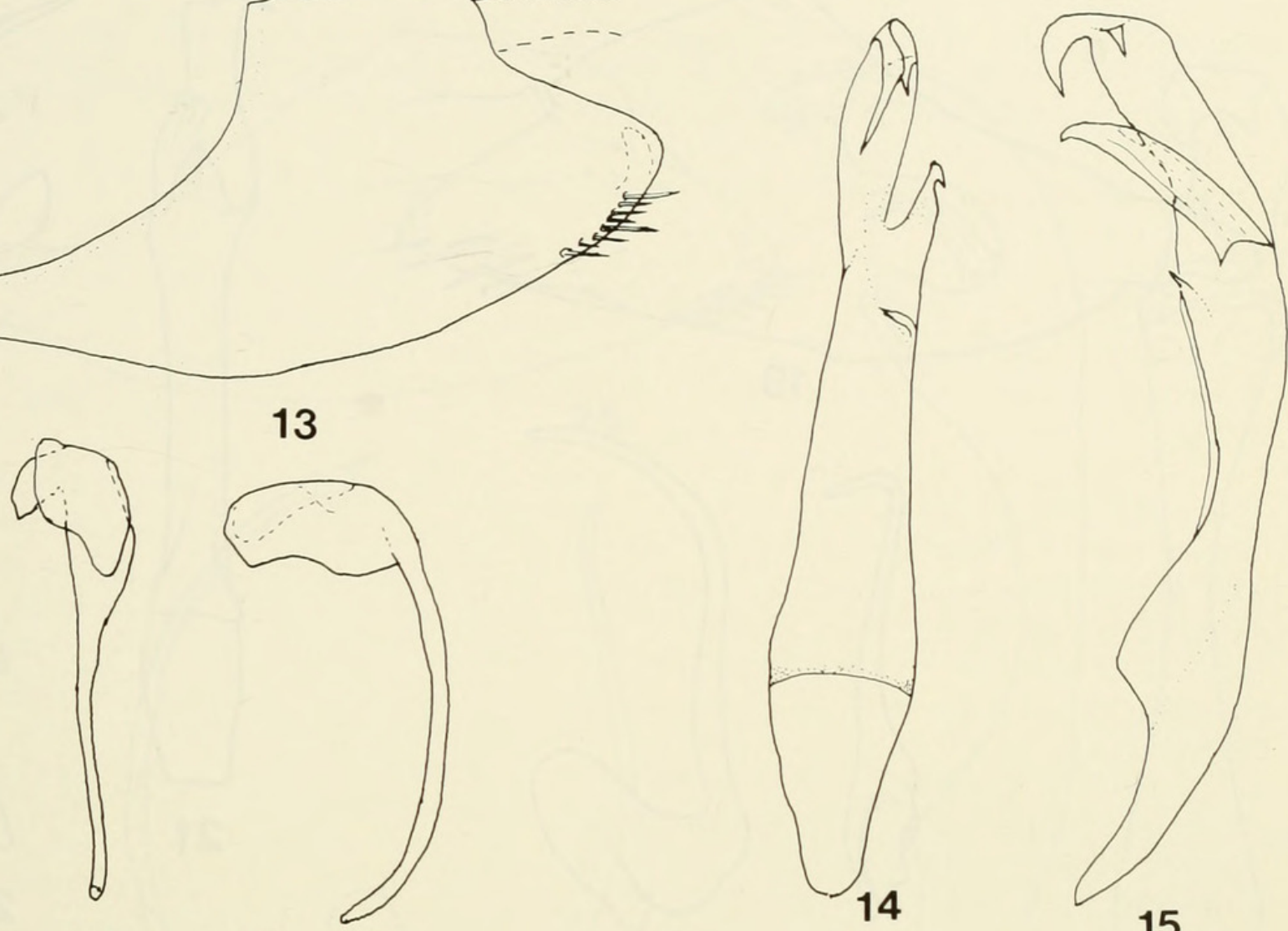

16

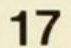

15

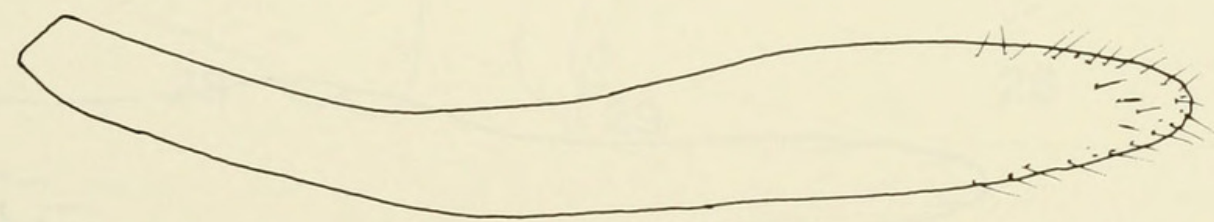

18

Figs. 13-18. Harasupia austini, n. sp.: 13, male pygofer, lateral view; 14, aedeagus, dorsal view; 15, aedeagus, lateral view; 16, style, dorsal view; 17 , style, lateral view; 18, plate, ventral view.

REMARKS.-This species can be distinguished from austini, n. sp. by its larger size, by the basal appendage of the aedeagus with enlarged basal rami and narrow distal rami containing the gonoduct, and by the distal appendage, which lacks a subdistal spine.

\section{Harasupia baja, n. sp.}

Figs. 25-30

LENGTH.-Male $6.20 \mathrm{~mm}$, female $6.60 \mathrm{~mm}$.

General color light to dark brown; crown yellowish; eyes dark brown; pronotum and scutellum tannish; forewings with veins blackish, cells mostly tannish translucent; face tan- nish. Similar to mexicana, n. sp. in some male genital characters.

Head narrower than pronotum; crown produced slightly beyond anterior margin of eyes, disc narrower than width of eyes in male, broader than eyes in female; pronotum shorter than median length of crown; scutellum with median length greater than median length of pronotum; forewings and venation typical; clypeus long and narrow, with faint but complete median longitudinal carina; clypellus narrow, lateral margins expanded distally.

MALE.-Pygofer in lateral view with small 


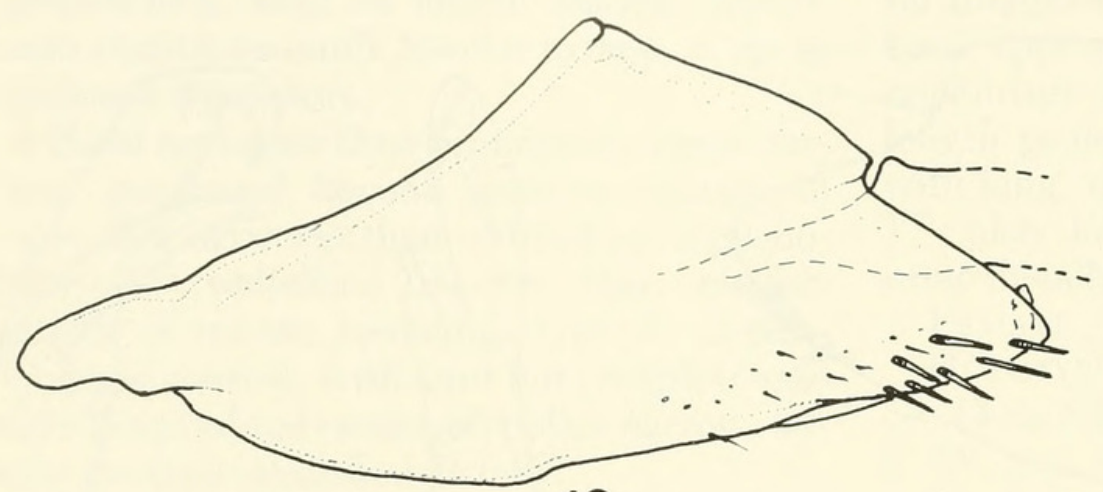

19
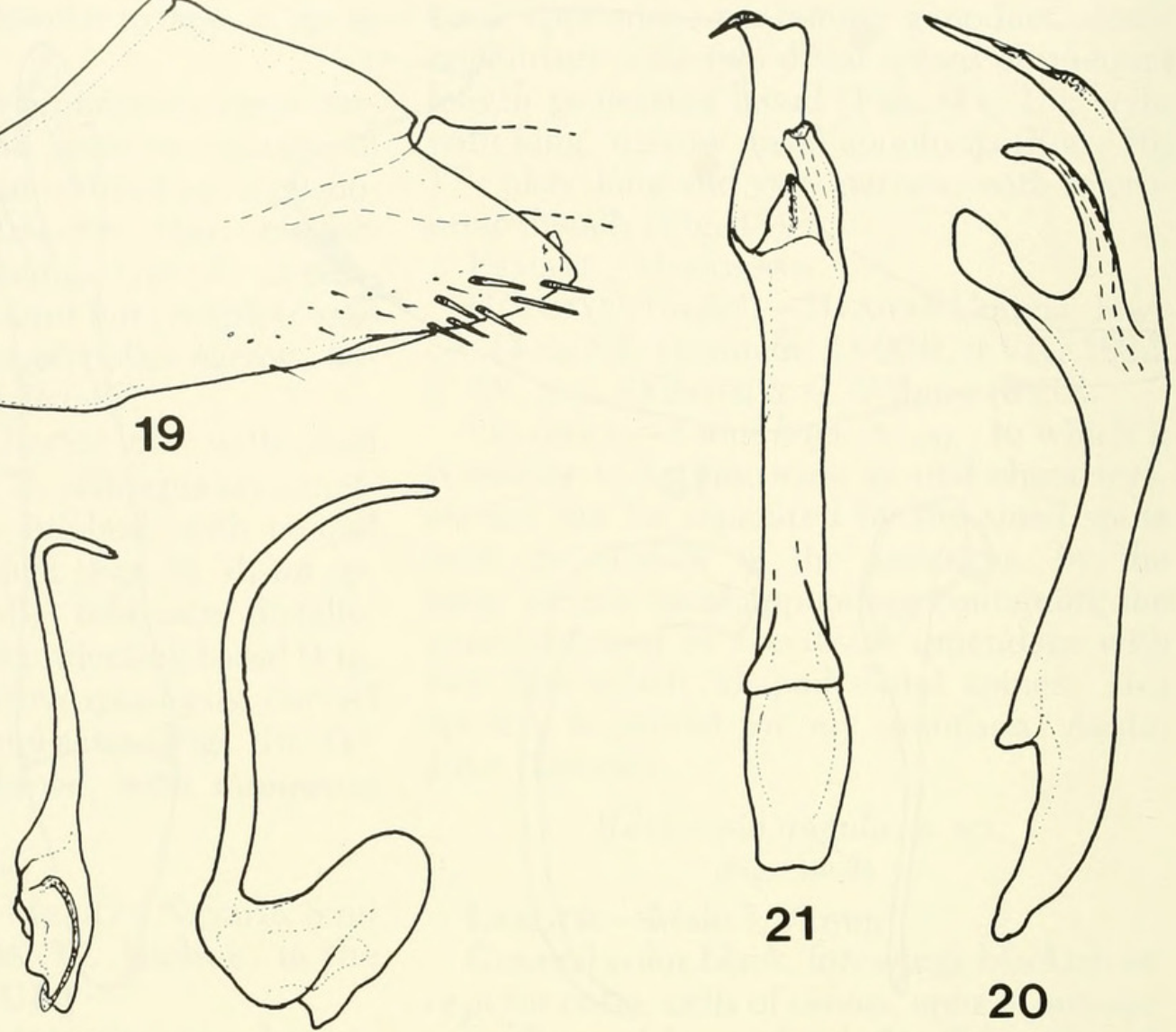

20

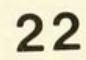

23

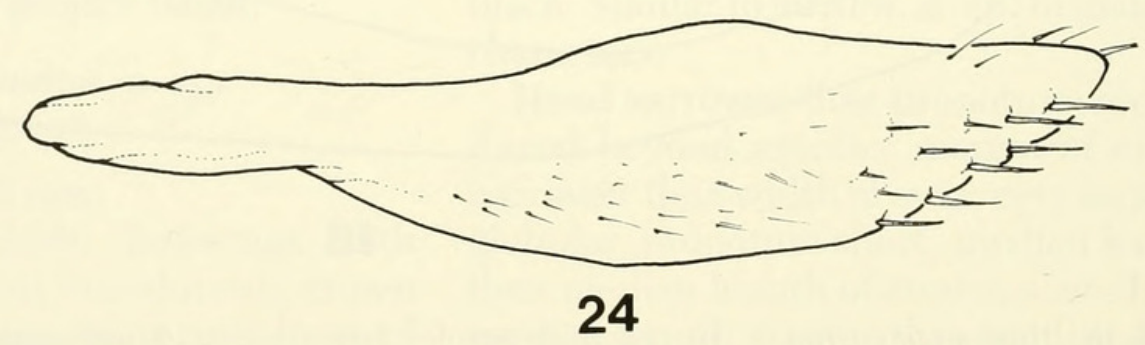

Figs. 19-24. Harasupia ungula, n. sp.: 19, male pygofer, lateral view; 20, aedeagus, lateral view; 21, aedeagus, dorsal view; 22 , style, dorsal view; 23 , style, lateral view; 24 , plate, ventral view.

caudodorsal lobe (Fig. 25); aedeagus asymmetrical, basal appendage bilobed with narrow process medially and containing gonoduct in lateral view, distal appendage enlarged medially in lateral view, shallowly and broadly emarginate distally in dorsal view (Figs. 26, 27); style with distal apophysis very long and narrow, slightly swollen subdistally (Figs. 28, 29); plate long and narrow, with numerous microsetae distally and on ventral margin (Fig. 30).

FEMALE.-Sternum seven with posterolateral angles produced.
Holotype (male).-Mexico: Baja California Sur, $4.3 \mathrm{~km}$ E La Burrera, $550 \mathrm{~m}$, canyonstream, 11-14.X.1978, Dozier \& Westcott (BYU). Allotype (female), same data as holotype (BYU).

RemaRKs.-Harasupia baja can be distinguished from mexicana, n. sp. by the small caudodorsal lobe on the male pygofer and by the lack of stylar setae. The holotype and allotype specimens are mounted on the same pin, with the male below the female. 

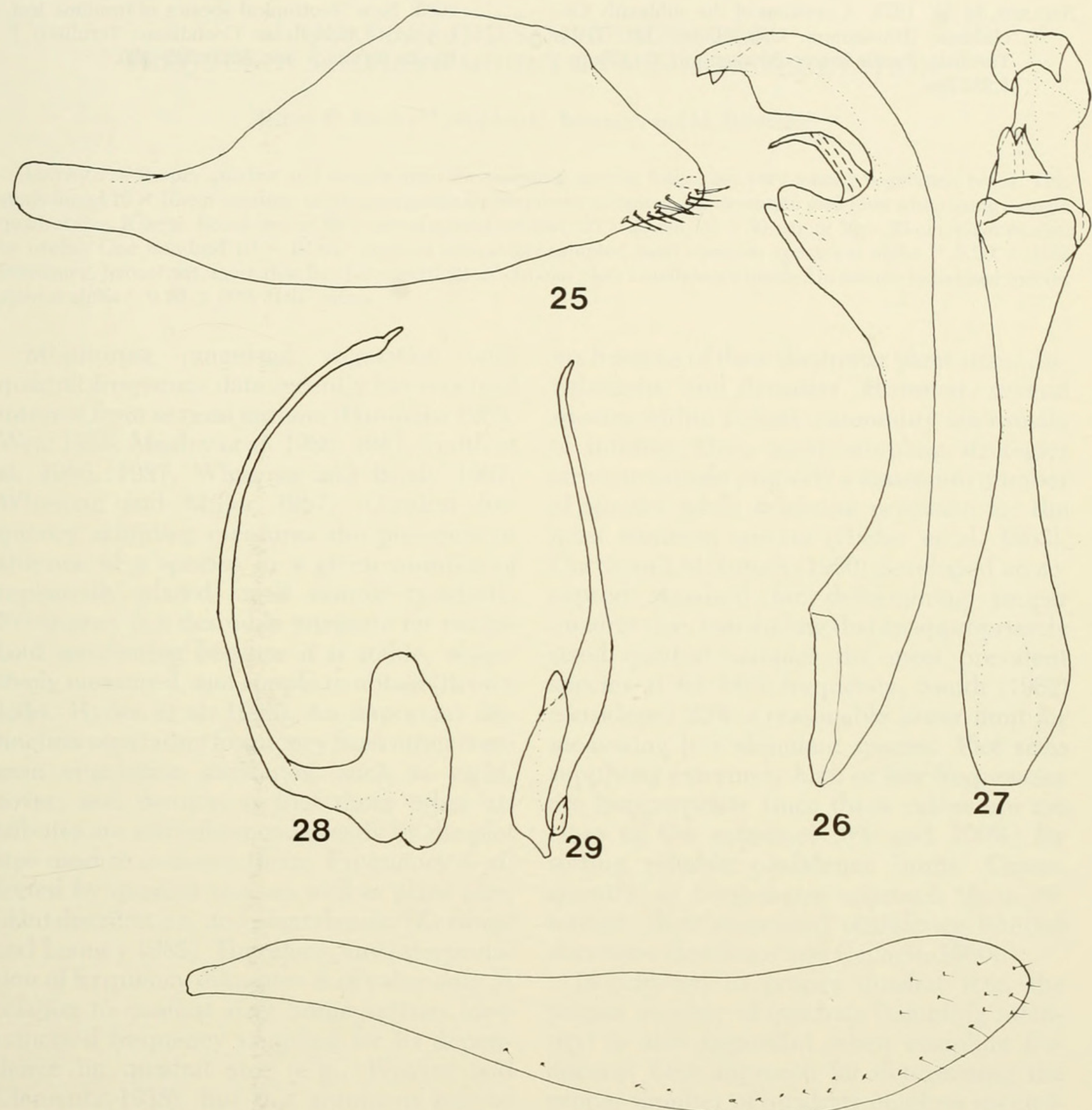

30

Figs. 25-30. Harasupia baja, n. sp.: 25, male pygofer, lateral view; 26, aedeagus, lateral view; 27, aedeagus, dorsal view; 28 , style, lateral view; 29 , style, dorsal view; 30 , plate, ventral view.

\section{ACKNOWLEDGMENTS}

Part of the material described here was borrowed from Agriculture Canada, Ottawa (CNC) through the kindness of Dr. K. G. A. Hamilton; the remainder was in the Monte L. Bean Life Science Museum, Brigham Young
University, Provo, Utah (BYU), and in my personal collection. I thank Dr. H. Derrick Blocker, Kansas State University, Manhattan, for reviewing the paper and Mrs. Jeanette Price for illustrating all of the species except austini and baja, which were done by the author. 


\section{Literature Cited}

Nielson, M. W. 1979. A revision of the subfamily Coelidiinae (Homoptera: Cicadellidae) III. Tribe Teruliini. Pacific Insects Monograph 35. 329 pp., 1,282 figs.
1983. New Neotropical species of teruliine leafhoppers (Cicadellidae: Coelidiinae: Teruliini). J. Kansas Entomol. Soc. 56(3): 365-370. 


\section{$2 \mathrm{BHL}$ Biodiversity Heritage Library}

1989. "New species of Harasupia with a revised key to the species

(Homoptera: Cicadellidae: Coelidiinae)." The Great Basin naturalist 49, 233-240. https://doi.org/10.5962/bhl.part.22644.

View This Item Online: $\underline{\text { https://www.biodiversitylibrary.org/item/33880 }}$

DOI: https://doi.org/10.5962/bhl.part.22644

Permalink: https://www.biodiversitylibrary.org/partpdf/22644

\section{Holding Institution}

Harvard University, Museum of Comparative Zoology, Ernst Mayr Library

\section{Sponsored by}

Harvard University, Museum of Comparative Zoology, Ernst Mayr Library

\section{Copyright \& Reuse}

Copyright Status: In copyright. Digitized with the permission of the rights holder.

License: http://creativecommons.org/licenses/by-nc-sa/3.0/

Rights: https://biodiversitylibrary.org/permissions

This document was created from content at the Biodiversity Heritage Library, the world's largest open access digital library for biodiversity literature and archives. Visit BHL at https://www.biodiversitylibrary.org. 